\title{
PowerbyProxi:
}

\section{Connecting the Unknown Dots in the Commercialisation of Inductive Power Transfer}

\author{
Brian Karlson \\ University of Auckland, Auckland, New Zealand \\ Nadine France \\ University of Auckland, Auckland, New Zealand \\ Cristiano Bellavitis \\ University of Auckland, Auckland, New Zealand \\ E-mail: c.bellavitis@auckland.ac.nz
}

Received: May 31, 2017 Accepted: June 5, 2017 Published: June 18, 2017

doi:10.5296/csbm.v4i2.11396 URL: http://dx.doi.org/10.5296/csbm.v4i2.11396

\begin{abstract}
This case describes New Zealand technology company PowerbyProxi, which was established by entrepreneurs Fady Mishriki and Greg Cross in 2007. PowerbyProxi developed a patented wireless slip ring designed for applications within the "wet, dirty and moving” industrial market and also offered breakthrough technology for wireless charging solutions for consumer electronics market. The case gives an overview of one research commercialisation experience through the lens of a New Zealand start-up. It depicts the challenges related to developing a viable product; identifying, creating and interacting with a market; securing intellectual property rights, and developing a business model.
\end{abstract}

Keywords: Product Development, Product Commercialization, Innovation, Entrepreneurial Finance 


\section{Introduction}

PowerbyProxi was founded by entrepreneurs Fady Mishriki and Greg Cross in 2007. The company was established to commercialise inductive power transfer (ICPT) research from The University of Auckland. PowerbyProxi was a combination of Mishriki's vision for wireless power and Cross' ability to identify and access international markets. (Note 1) Mishriki had worked on various applications technology for three years, before the pair identified a potential application area and found their first paying customer. The resulting co-developed product led to the exploration of other promising industrial markets where the technology could add value. PowerbyProxi had also been working on wireless charging solutions for consumer electronics and in 2013 joined the US-based Wireless Power Consortium (WPC).

However, despite these positive developments, uncertainty remained. By 2012 PowerbyProxi had offices in New Zealand and the US, and employed a team of 24 staff. Having used its extensive IP portfolio to build applications for approximately 50 Fortune 500 companies over the past four years, the firm hoped to become profitable in 2013. (Note 2)

\section{Background}

Fady Mishriki immigrated to New Zealand from Bahrain with his family in 1999. The following year he began studying at The University of Auckland, and in 2003 began his final-year engineering project with friend Kunal Bhargava, supervised by Dr Patrick Hu. The project was to build a commercial application for electronics business Actronic, using inductive power transfer (ICPT) research. ICPT transferred electricity between transmitter and receiver using magnetic fields rather than cables, allowing each unit to be individually sealed. (Note 3) The research had been pioneered by The University of Auckland Professor John Boys and Associate Professor Grant Covic two decades before, and resulted in more than 50 patent families. (Note 4) Hu had expanded on the research after he moved to New Zealand in 1996 to earn a PhD, resulting in five patents in ICPT and micro-computer control technologies. (Note 5) All ICPT patents were held by UniServices, the commercialisation arm of The University of Auckland, which had licensed the technology for a number of applications including electric cars, traffic control studs, and physiological monitoring equipment.

While studying, Mishriki also explored other possibilities for applying ICPT to consumer products. (Note 6) A contact at GPS navigation company Navman identified a potential use for fish finder devices which were attached to the bottom of boats but required a hole drilled through the floor to connect the device to a power source. To solve the problem, Mishriki and Bhargava developed a prototype of a self-enclosed module which transferred electricity without a direct wire connection, at a cost of NZ\$100. (Note 7) They entered the prototype with their venture Contactless Technologies into the Spark $\$ 40 \mathrm{~K}$ Challenge, an entrepreneurship competition at The University of Auckland Business School. The duo came second and won \$10,000 in seed capital. (Note 8) In November 2004, Mishriki and Bhargava entered The ICEHOUSE business pre-incubation programme and undertook market research and validation of the project. In line with entrepreneurial finance literature, belonging to the 
incubator provided important resources (e.g., Bellavitis, Filatotchev, Kamuriwo, \& Vanacker, 2017; Bellavitis, Filatotchev, \& Kamuriwo, 2014) However, Navman was going through changes and the project was cancelled shortly after.

Mishriki turned his focus towards developing an ICPT application to sell into the consumer electronics industry. He was aware of British start-up company Splashpower Ltd, which was developing a wireless charger for portable devices like mobile phones, mp3 players and cameras. Splashpower raised $£ 30$ million in venture capital and developed a SplashPad receiver that could be retrofitted to existing devices. Despite Splashpower's success in raising capital, Mishriki believed that its concept was flawed. "Consumers were never going to adopt a solution that made devices big and clunky. They were selling retro fits, a massive thing you had to attach to your phone.” (Note 9) Instead, he wanted to create a miniaturised wireless charger that could be embedded in a device and add value to the customer experience.

Mishriki researched the market viability of his idea and the potential adoption of large electronics companies such as Nokia or Sony Ericsson. The consumer electronics industry was dominated by large international corporations, and suppliers needed to prove they were financially sound, their product could integrate successfully with the company's existing range, and they had a strong distribution network. The product needed to be high quality and easily scalable. (Note 10) Mishriki worked on the wireless charger project for roughly 18 months, funding himself through contract work. He believed he "had significant technological challenges to overcome" to get the application small and cheap enough to be commercially viable. (Note 11) In December 2004 he used the \$10,000 seed money won at the $\$ 40 \mathrm{~K}$ Challenge and used personal funds to "bootstrap" the business. He approached UniServices to begin negotiating a licence for ICPT in the consumer industry, but despite regular meetings the negotiations failed to succeed. UniServices preferred to grant licences for specific, discreet markets and was unwilling to grant a broad licence that covered the entire consumer industry.

\section{Early Commercialisation Stage: Searching for a Direction}

In mid-2006, Mishriki approached The ICEHOUSE to help him find a business partner who had sales and marketing experience to complement his engineering background. Helping with key human resources is one way investors can support a portfolio company (Bellavitis, Filatotchev, \& Souitaris, 2017; Hellmann \& Puri, 2002) He was introduced to different people and realized the importance of finding the right partner (Abatecola, Mandarelli, \& Poggesi, 2013). "When I met Greg Cross we connected, and I recognised our skills were quite complimentary and we could work together." (Note 12) Cross had a background in marketing and had held senior roles at Bellsouth, Microsoft New Zealand, and the Advantage Group. He was chairman of the New Zealand Trade and Enterprise (NZTE) Beachheads programme and had a history of successfully investing in entrepreneurial firms. The pair met weekly for six months to explore whether they were compatible enough to start a business together. Cross also conducted due diligence on the opportunities that ICPT presented. "What I look for in new ventures is what I call unfair competitive advantage. The key point for me 
was understanding the depth of the ICPT intellectual property that was at The University of Auckland, and how that could provide a platform for building something at could be very competitive on the world stage.” (Note 13) Cross and Mishriki decided to work together to find a commercial application for ICPT and named their company PowerbyProxi.

Cross and Mishriki began market research within consumer and industrial markets and concluded that the consumer industry was not ready to adopt the wireless charger. "It wasn't that we realised it wasn't going to work, it was that we realised it wasn't going to work now." (Note 14) They saw that companies attempting to develop for the consumer electronics market were not yet able to come up with an appealing solution. (Note 15) Instead, Mishriki and Cross worked on developing a value proposition for ICPT in the industrial market, focussing on hostile and challenging application areas. Cross said that the focus on the industrial space came from "largely gut instinct" and that initially, they had no clear idea about where specifically the technology could add value. "We realised that mechanical connectors fail in wet and dirty environments, so decided to go test that market." (Note 16) Cross wanted to bootstrap the business by getting a paying customer on board. Mishriki recalled: “We didn’t build anything, we didn't invest in technology. We had cobbled together a demo pad [a wireless transmitter and receiver pad which demonstrated the technology at a scale of two watts] that we built with parts from Payless Plastics and stuck some electronic boards inside them.” (Note 17) They also developed a PowerPoint presentation to demonstrate the applicability of ICPT to customers, without identifying specific products, and "started knocking on doors." (Note 18)

Mishriki approached a contact at Waratah Forestry Attachments in Tokoroa (New Zealand), a subsidiary of John Deere Ltd, and gained the opportunity to speak to Waratah's managing director. He saw a potential use for ICPT within John Deere as the company was looking for a way to make swivelling parts of certain machinery continuously rotate $360^{\circ}$. At that stage, the only way to achieve continuous rotation was to use an unreliable mechanical slip ring. (Note 19) John Deere's competitors used a mechanical slip ring to offer $360^{\circ}$ rotation despite the difficulties, and the company was losing market share. Waratah's managing director sponsored PowerbyProxi to pitch the idea higher up in the company. "When the executives heard about wireless power they said, can you use it to do this? At the time, we were doing two watts and they wanted 240 watts. So we put a proposal to them, including what we would need from them, and they signed off on it.” (Note 20)

PowerbyProxi and John Deere signed an agreement in July 2007 after three months of negotiation. John Deere paid a significant sum in three tranches that would become PowerbyProxi's seed capital to develop and test a working prototype for a wireless slip ring. The product was planned to be used in the next generation of forestry harvester heads. To receive the funding, PowerbyProxi had to meet three developmental milestones and have a working product within 12 months. The agreement gave John Deere exclusive use of the product in the agricultural machinery field for a few years and in return it committed to buying a certain volume of the resulting product. Mishriki and Cross believed that granting John Deere exclusivity was acceptable terms given the firm's dominance of the market. (Note 21) 
PowerbyProxi directly employed two permanent new research and development staff, four staff through consulting contracts with UniServices, and rented space in The University of Auckland laboratories. However, the company was still facing a high level of technical uncertainty. Mishriki believed: “There was absolutely a concern that the project wasn't going to work. The first version of the wireless slip ring was built off University IP and it would just cook itself. The challenge was we were putting this thing into such an enclosed form factor, completely surrounded by masses of metal.” Despite the financial risk for them, John Deere was willing to commit to the project in light of the potential payoff. (Note 22)

Mishriki and Cross approached UniServices to reopen negotiations to license ICPT for the industrial slip ring market. This time PowerbyProxi had a paying customer on board and a specific focus, as well as the credibility provided by Cross's background. These signals proved crucial (Kamuriwo, Hommel and Bellavitis, forthcoming). PowerbyProxi and UniServices signed an agreement in August 2007, in which UniServices gained a licensing fee and royalties on any products developed as a result of the IP, and ten per cent of the company. (Note 23) PowerbyProxi used the UniServices IP as a starting point for their research and, in the course of creating the product for John Deere, developed an independent body of IP. They produced a working wireless slip ring for John Deere within the twelve-month timeframe, hitting each of their milestones. The slip ring promised increased reliability and decreased maintenance costs and could conduct electricity through most materials. As part of the development PowerbyProxi also built a data communications system for the slip ring after Deere's initial supplier fell through. Because at that stage they had no expertise in the field of data communications, they hired a specialist and developed a wireless communication system that could produce industrial protocols without any specific programme. The resulting technology subsequently became "another core staple of our offering.” (Note 24)

In July 2008, after 12 months of joint development effort with John Deere, PowerByProxi had its first branded product ready-the Proxi-Ring. (Note 25) Following the successful development of the prototype, PowerbyProxi initially planned to "work through several pilot phases of increasing numbers of products. Then, if the slip ring went in to full production we'd manufacture 4,000-5,000 units per year [for John Deere], delivering finished products using a contract manufacturer." At the time, John Deere shipped between four and five thousand rotating forestry heads per year, which might have made PowerbyProxi up to US\$5 million annually. (Note 26) However, in October 2008 the global economy entered a recession and the number of forestry heads shipped annually by John Deere dropped to 50 . The company postponed the release of the wireless rotating harvester head for an indefinite period of time.

\section{Development Stage: Shaping a Business Case}

Having identified the slip ring market as a potentially lucrative application area and having developed their first product but not the sales that were initially anticipated, Mishriki and Cross wanted "essentially to sell product." (Note 27) They had a contract manufacturer at hand and planned to sell the product but after talking to and educating various companies 
about their product, soon realised that many businesses would have their own manufacturing facilities. Instead of pushing their product out into the market, Mishriki and Cross decided to license their technology. "We didn't want to manufacture products for every single customer under the sun. It made better sense for us to license the technology to existing slip ring companies, and have them push the product into their existing channels and industry relationships.” Mishriki and Cross visited every major slip ring manufacturer in the US (Note 28) but they had little success and Mishriki felt manufacturers were resistant to products developed outside of the US. Existing companies also had "a great spare parts business selling replacement brushes.” (Note 29) PowerbyProxi eventually signed an agreement with UEA-Inc, a slip ring manufacturer based in Iowa. However, while the owner himself was committed to the product and willing to fund the project, his sales staff struggled to understand the electronics concepts and the deal did not translate into sales. (Note 30) Mishriki and Cross had been "optimistic that somebody would get it. But when month after month that didn’t really start to happen we decided we'd just keep going ourselves. Let's pick a niche in the market, and focus on that market.” (Note 31)

By 2008 the company needed capital, especially since the John Deere sales did not go through as initially anticipated and due to the difficulty of attracting other customers. Mishriki noted: "If our slip ring road show had worked out and we had more adoption then we probably wouldn't have needed to raise capital. But we just couldn't get the engagement from the manufacturers. So we'd set up our own office, were doing it ourselves, and needed to raise capital." (Note 32) In January 2009, PowerbyProxi raised funds from Wellington-based investment group Movac and private company Evander Management Ltd. The capital was delivered in two tranches in return for equity stakes in the company. Disbursing capital in tranches is an efficient way to reduce investors' risk (Wang \& Zhou, 2004). Mishriki and Cross set up an office in Alpharetta (Georgia), USA and employed a new business development manager with knowledge of the US market. During discussions with John Deere, Mishriki and Cross came up with four sub-categories where they thought potential customer could use wireless power. This resulted in what would become the Proxi-Ring, the Proxi-Point (one-to-one wireless power transfer, for powering sensors in hard-to-reach locations), Proxi-Loom (powering multiple sensors from a track loop), and Proxi-Fi (miniaturised wireless power receiver, based on Mishriki's original investigation into the consumer industry). Having introduced these concepts "proved to be a very good way to engage a wide variety of people.” (Note 33) Mishriki and Cross identified potential customers through "a mix of networking, hiring people with established contacts, trade shows, and good old fashioned cold calling.” (Note 34)

Mishriki and Cross discovered that the fastest growing segment for slip rings was wind turbines, which operated in wet, dirty and difficult environments and could cost thousands of dollars in lost revenue during a breakdown. Wind energy was a growing industry in the US due to the Federal Electricity Production Tax Credit (PTC), which returned 2.2c per kilowatt hour of renewable power generated to developers. (Note 35) Wind generation capacity in the US grew from only 5GW in 2003 to $25.36 \mathrm{GW}$ in 2008 (Note 36), and in 2008 a record $8.5 \mathrm{GW}$ of capacity was installed, more than 80 percent higher than the previous record. (Note 
37) The PTC was credited with incentivising \$15 billion per year in private investment in US wind farms. (Note 38) Mishriki and Cross started approaching wind turbine manufacturers and companies that maintained wind farms. During the process the duo learned that wireless slips ring could potentially serve two markets: they could be integrated into the design of a new generation turbine as well as retrofitted to an existing device. (Note 39)

In 2009, PowerbyProxi entered an agreement with GE Energy, a division of General Electric which manufactured equipment for the energy generation industry and had produced almost half of the total US wind power fleet. (Note 40) At the time, Mishriki and Cross anticipated that it would take 12 to 18 months to get their product designed into the turbine and start realising licensing revenue but the development and potential generation of revenue turned out to be "much slower than our original assumptions." They learned that the process would typically take between three and five years. PowerbyProxi also signed an agreement with IM Future, a Spanish owned wind turbine maintenance company which oversaw 3,000 turbines in 400 farms across Europe. IM Future paid PowerbyProxi to develop a wireless slip ring to retro-fit to their existing turbines, which would be tested in Spain. (Note 41)

However, by 2011 the wind industry in the US was hit by the recession and by the uncertainty over whether the PTC would be renewed after December 2012. Developers were hesitant to develop or expand new wind farms without confirmation of the credit, and original equipment manufacturers (OEMs), including Siemens, reduced staff numbers in manufacturing facilities. Likewise, EU countries including Spain, the UK, Germany, Italy, the Netherlands and France reduced or eliminated subsidies for new clean energy development, including wind power. In January 2012 Spain cancelled all subsidies for new wind power projects, after investing $\$ 69$ billion in wind power over the preceding decade, with a potential knock on effect in other parts of Europe as banks became hesitant to lend to renewable energy projects. Consequently, OEMs would drastically decrease design and development of new wind turbines. (Note 42) Although PowerbyProxi continued to work with GE, the main focus was on the retro-fit market. In July 2011, Mishriki announced the successful eight-month Spanish trial of the Proxi-Ring at IM Future, which planned to roll out the Proxi-Ring technology across 20 wind farms (around 500 wind turbines) under its management over the next three years. (Note 43) In 2011, PowerbyProxi also received funding from Movac, this time co-invested by New Zealand Venture Investment Fund (NZVIF), as the result of a second venture capital round.

In 2012, PowerbyProxi moved into its first commercial production with an international manufacturer of materials handling and lift truck attachments. PowerbyProxi was approached by the firm and together they worked on a cordless power and data transfer solution. (Note 44) PowerbyProxi built them a wireless receiver for the tip of a forklift which transmitted data back to the body of the lift, and could be wirelessly charged when the fork was in a neutral position. The agreement included delivery of the components and PowerbyProxi outsourced the manufacturing. Cross considered the company "a design house. At the end of the day we stay good at designing and we outsource to contractors everything else.” (Note 45) PowerbyProxi focused on licensing its technological platform and receiving royalty fees for the units sold by its customers. This model led it to build approximately 50 wireless power 
applications for Fortune 500 companies over four years. (Note 46)

\section{Aftermath and Lessons Learned}

In October 2012 PowerbyProxi secured the exclusive rights for a patent portfolio from The University of Auckland (Note 47), extending its IP portfolio to 125 patents worldwide at various stages of filing. This enabled the company to further develop "capabilities for wireless power including multi-axis, position-free, and extended reach wireless power charging," all attributes that are thought after for wireless charging of consumer electronic products. So far, PowerbyProxi could develop breakthrough technology that could be integrated into mobile communication devices such as smartphones and tablets and into rechargeable batteries. (Note 48) In early 2013, PowerbyProxi launched the In-Device charging unit, the world's first of its kind (Note 49) that allowed charging devices using rechargeable AA batteries that the firm developed, Proxi-Fi AA.

In April 2013, US conglomerate TE Connectivity acquired a 15 percent shareholding in PowerbyProxi that partially contributed to a total funding of US\$5 million. Movac was also again part of this $\mathrm{C}$ series funding round and increased its shareholding to 40 percent. TE Connectivity, previously known as Tyco, employed about 90,000 staff worldwide and achieved annual revenues of about US\$1.2billion. PowerbyProxi and TE Connectivity had already collaborated for product development. The ARISO Contactless Connectivity Platform, which was solely marketed by TE, provided a miniaturised non-contact connectivity solution that could be integrated in various industrial equipment applications. (Note 50)

In May 2013, PowerbyProxi joined the US-based Wireless Power Consortium (WPC). The consortium was formed at the end of 2008, planning to establish a global standard for wireless charging of electronic products. (Note 51) Their standard "Qi" had already been integrated in various consumer electronics, particularly smartphones, and PowerbyProxi was planning to develop technology that fitted in the Qi eco-system. (Note 52) As a privately held company, PowerbyProxi has not disclosed any financial information but was confident it would become profitable in 2013. (Note 53)

\section{Conclusion}

Five years after its founding in 2007, PowerbyProxi was hotly tipped as one of New Zealand's "potentially most lucrative export opportunities in recent times." (Note 54) In September 2012 it employed 24 people in offices in New Zealand and the US, the majority being engineers. (Note 55) By 2013 it had worked with more than 50 international customers and had since launched additional technology solutions in a broad range of applications in the industrial market and also began to move into the consumer electronics market. (Note 56) As a design company, PowerbyProxi did not anticipate to manufacture finished products but rather focussed entirely on developing technology solutions that would be licensed.

In the early commercialisations stage, PowerbyProxi explored different application areas over time. Its first product was developed in collaboration with its first customer in the forestry sector but due to unforeseeable circumstances did not translate into profits. Having identified a product and a market, Mishriki and Cross raised capital through external funding and 
looked at the US market where they approached several companies. It turned out to be more difficult than expected, especially due to initial resistance and ignorance of potential customers towards the technology. However, they hired a US-based business developer, continued to approach firms, attended trade shows and eventually succeeded in getting customers in the wind industry aboard which, again, was disrupted by industry developments. Holding about 125 patents worldwide, PowerbyProxi has since explored opportunities in other industries, extended its platform portfolio, and developed applications for both industrial and electrical consumer markets. However, uncertainty remains high. The nascent wireless charging market was highly contested (Note 57) and despite the recent positive outlooks, for example, in the wind industry, (Note 58) such sectors could easily be disrupted by unforeseen events.

Timeline of key events

\begin{tabular}{|c|c|}
\hline Year & Event \\
\hline 2004 & $\begin{array}{l}\text { Mishriki and Bhargava enter \$40k Spark Challenge with prototype of wireless electricity transfer device } \\
\text { and win } \$ 10,000 \text { seed capital }\end{array}$ \\
\hline 2004 & $\begin{array}{l}\text { Mishriki and Bhargava enter The ICEHOUSE business pre-incubation } \\
\text { programme to undertake market research and further technology research }\end{array}$ \\
\hline 2004 & Sponsor company cancels the project due to firm-internal disruptions \\
\hline 2005 & $\begin{array}{l}\text { Mishriki bootstraps the business and starts first round of negotiations with UniServices regarding IP } \\
\text { licence }\end{array}$ \\
\hline 2006 & $\begin{array}{l}\text { Mishriki approaches The ICEHOUSE to find a business partner and gets } \\
\text { introduced to Cross }\end{array}$ \\
\hline 2007 & Mishriki and Cross incorporate PowerbyProxi \\
\hline \multirow[t]{2}{*}{2007} & Mishriki approaches Watarah, subsidiary of John Deere Ltd. \\
\hline & $\begin{array}{l}\text { Funding of seed capital by John Deere to develop a prototype for a wireless slip } \\
\text { ring for forestry harvester heads where John Deere commits to buy a minimum volume of resulting } \\
\text { product }\end{array}$ \\
\hline 2007 & $\begin{array}{l}\text { Renegotiations with UniServices regarding slip ring IP where UniServices } \\
\text { gained a licensing fee and royalties as well as } 10 \text { percent company share }\end{array}$ \\
\hline 2008 & $\begin{array}{l}\text { Recession leads John Deere to postpone the release of the wireless rotating } \\
\text { harvester }\end{array}$ \\
\hline 2008 & Road show in the US to approach slip ring manufacturers \\
\hline 2008 & Initial agreement with US-based slip ring manufacturer UEA-Inc \\
\hline 2009 & $\begin{array}{l}\text { PowerbyProxi raises funding from Wellington-based investment manager } \\
\text { Movac and private company Evander Management Ltd }\end{array}$ \\
\hline 2009 & $\begin{array}{l}\text { PowerbyProxi opens sales and marketing office in Alpharetta, Georgia, and employed a US-based } \\
\text { business development manager }\end{array}$ \\
\hline 2009 & $\begin{array}{l}\text { PowerbyProxi enters agreements with US-based GE Energy and Spain-based } \\
\text { IM Future }\end{array}$ \\
\hline 2011 & IM Future rolls out PowerbyProxi’s Proxi-Ring 480 after eight months trial \\
\hline 2011 & $\begin{array}{l}\text { PowerbyProxi receives investment from Movac, co-invested by New Zealand } \\
\text { Venture Investment Fund (NZVIF) in second investment round }\end{array}$ \\
\hline 2012 & $\begin{array}{l}\text { PowerbyProxi gets exclusive rights to UniService’s wireless power patent } \\
\text { portfolio }\end{array}$ \\
\hline 2013 & $\begin{array}{l}\text { PowerbyProxi secures funding of \$5 million in Series C funding round and } \\
\text { enters a partnership agreement with US-based TE Connectivity }\end{array}$ \\
\hline 2013 & PowerbyProxi joins US-based global consortium WPC \\
\hline 2013 & Launch of Proxi In-Device targeted at the consumer electronics market \\
\hline
\end{tabular}




\section{References}

Abatecola, G., Mandarelli, G., \& Poggesi, S. (2013). The personality factor: How top management teams make decisions. A literature review. Journal of Management and Governance, 17(4), 1073-1100. https://doi.org/10.1007/s10997-011-9189-y

Bellavitis, C., Filatotchev, I., \& Kamuriwo, D. S. (2014). The effects of intra-industry and extra-industry networks on performance: A case of venture capital portfolio firms. Managerial and Decision Economics, 35(2), 129-144. https://doi.org/10.1111/1467-8551.12162

Bellavitis, C., Filatotchev, I., \& Souitaris, V. (2016). The impact of investment networks on venture capital firm performance: A contingency framework. British Journal of Management, 28(1), 102-119. https://doi.org/10.1111/1467-8551.12162

Bellavitis, C., Filatotchev, I., Kamuriwo, D. S., \& Vanacker, T. (2017). Entrepreneurial finance: new frontiers of research and practice: Editorial for the special issue Embracing entrepreneurial funding innovations. Venture Capital, 19(1-2), 1-16. https://doi.org/10.1080/13691066.2016.1259733

Bellavitis, C., Kamuriwo, D. S., \& Hommel, U. (Forthcoming). Mitigating moral hazard and adverse selection in venture capital industry. Journal of Small Business Management.

Hellmann, T., \& Puri, M. (2002). Venture capital and the professionalization of start-up firms: Empirical evidence. Journal of Finance, 57(1), 169-197. https://doi.org/10.1111/1540-6261.00419

Wang, S., \& Zhou, H. (2004). Staged financing in venture capital: Moral hazard and risks. Journal of Corporate Finance, 10, 131-155. https://doi.org/10.1016/S0929-1199(02)00045-7

\section{Notes}

Note 1. Movac. (2011). PowerbyProxi and Minimonos in top 10 for BNZ Virgin Business Challenge. [Online] Available: http://movac.co.nz/category/news/

Note 2. Keall, C. (2013). US tech conglomerate buys into Auckland's PowerbyProxi. The National Business Review. [Online] Available: http://www.nbr.co.nz.ezproxy.auckland.ac.nz/article/us-tech-conglomerate-buys-aucklands-po werbyproxi-ck-138762

Note 3. Foundation for Research, Science and Technology. Power up without plugging in. 2 November 2009. Media release.

Note 4.4 Uniservices Website, http://www.uniservices.co.nz/LinkClick.aspx?fileticket=Mr77beMVS1U\%3d\&tabid=614

Note 5. http://web.ece.auckland.ac.nz/uoa/patrick-hu

Note 6. Fady Mishriki. Personal Communication. June 2012. 
Note 7. http://www.ipenz.org.nz/ipenz/publications/dimension/2004/Dim_Apr04.pdf

Note 8. The University of Auckland. (2004). Ingenio et labore-Magazine of The University of Auckland. [Online] Available: https://www.alumni.auckland.ac.nz/webdav/site/alumni/shared/publications/ingenio/ingenio_autu mn04_we b.pdf

Note 9. Fady Mishriki. Personal Communication. June 2012.

Note 10. Datamonitor. (2010). Global Consumer Electronics Industry Report. p. 12.

Note 11. Fady Mishriki. Personal Communication. June 2012.

Note 12. Fady Mishriki. Personal Communication. June 2012.

Note 13. Greg Cross. Personal Communication. September 2012.

Note 14. Fady Mishriki. Personal Communication. June 2012.

Note 15. Fady Mishriki. Personal Communication. June 2012.

Note 16. Greg Cross. Personal Communication. September 2012.

Note 17. Fady Mishriki. Personal Communication. June 2012.

Note 18. Greg Cross. Personal Communication. September 2012.

Note 19. A traditional mechanical slip ring supplies power to a rotating joint by transferring an electric current from a stationary to a rotating unit, via a graphite brush which contacting the electrical current to the outside diameter of a rotating metal ring.

Note 20. Fady Mishriki. Personal Communication. June 2012.

Note 21. Datamonitor. (2010). Global Construction, Farm Machinery, Heavy Trucks Report. Retrieved from Datamonitor database.

Note 22. Fady Mishriki. Personal Communication. June 2012.

Note 23. Greg Cross. Personal Communication. September 2012.

Note 24. Fady Mishriki. Personal Communication. June 2012.

Note 25. PowerbyProxi. (2008, July 15). PowerbyProxi completes development of the world's first wireless slip ring-PowerbyProxi. [Online] Available: http://www.powerbyproxi.com/2008/07/powerbyproxi-completes-development-of-the-worlds -first-wireless-slip-ring/

Note 26. Greg Cross. Personal Communication. September 2012.

Note 27. Fady Mishriki. Personal Communication. June 2012.

Note 28. Fady Mishriki. Personal Communication. June 2012.

Note 29. Fady Mishriki. Personal Communication. June 2012. 
Note 30. Greg Cross. Personal Communication. September 2012.

Note 31. Greg Cross. Personal Communication. September 2012.

Note 32. Fady Mishriki. Personal Communication. June 2012.

Note 33. Greg Cross. Personal Communication. September 2012.

Note 34. Fady Mishriki. Personal Communication. June 2012.

Note 35. AWEA press release. Sep 18, 2012.

Note 36. http://www.nrel.gov/docs/fy09osti/46026.pdf

Note 37. http://www.nrel.gov/docs/fy09osti/46026.pdf

Note 38. http://www.awea.org/newsroom/pressreleases/3q2012release.cfm

Note 39. Greg Cross. Personal Communication. September 2012.

Note 40. AWEA American Wind Energy Association. Annual Market Report: Rankings. p. 2.

Note 41. Greg Cross. Personal Communication. September 2012.

Note 42. Morales, A., \& Sills, B. (2012, May 31). Spain Ejects Clean-Power Industry with Europe Precedent: Energy. Bloomberg. [Online] Available: http://www.bloomberg.com/news/2012-05-29/spain-ejects-clean-power-industry-with-europe -precedent-energy.html

Note 43. Keall, C. (2011). NZ's PowerbyProxi in Spanish windfarm deal. The National Business Review. [Online] Available: http://www.nbr.co.nz.ezproxy.auckland.ac.nz/article/nzs-powerbyproxi-spanish-windfarm-dea l-ck-93900

Note 44. Terkosky, D. (2012). All wrapped up and no place to go. PowerbyProxi. [Online] Available: http://www.powerbyproxi.com/2012/08/all-wrapped-place-go/

Note 45. Greg Cross. Personal Communication. September 2012.

Note 46. PowerbyProxi. (2013). IP Portfolio. [Online] Available: http://www.powerbyproxi.com/innovations/ip-portfolio/

Note 47. PR Newswire. (2012). Power by Proxi Secures Exclusive Rights To the University of Auckland's Wireless Power Technologies Developed for Use In Consumer Electronics. [Online] Available: http://www.virtualizationconference.com/node/2425019

Note 48. Whyte, P. (2013). New Zealand company leads world with wireless recharging. New Zealand Engineering News. [Online] Available: http://www.powerbyproxi.com/communications/news/new-zealand-company-leads-world-wit h-wireless-recharging/

Note 49. PowerbyProxi. (2013). Proxi In-Device Charging Solution. PowerbyProxi. Company website. [Online] Available: 
http://www.powerbyproxi.com/innovations/consumer/proxi-in-device-charging-solution/

Note 50. Whyte, P. (2013). New Zealand company leads world with wireless recharging. New Zealand Engineering News. [Online] Available: http://www.powerbyproxi.com/communications/news/new-zealand-company-leads-world-wit h-wireless-recharging/

Note 51. PowerbyProxi Joins Wireless Power Consortium. (2013). BusinessWire. [Online] Available:

http://www.businesswire.com/news/home/20130513005414/en/PowerbyProxi-Joins-Wireless -Power- Consortium

Note 52. Mishriki, F. (2013). Interoperability—you know you want it. PowerbyProxi. [Online] Available: http://www.powerbyproxi.com/2013/06/interoperability-you-know-you-want-it/

Note 53. Keall, C. (2013). US tech conglomerate buys into Auckland's PowerbyProxi. The National Business Review. [Online] Available: http://www.nbr.co.nz.ezproxy.auckland.ac.nz/article/us-tech-conglomerate-buys-aucklands-po werbyproxi-ck-138762

Note 54. On the charge. (2013). NZ Business, 27(2), 40-41.

Note 55. Greg Cross. Personal Communication. September 2012.

Note 56. Whyte, P. (2013). New Zealand company leads world with wireless recharging. New Zealand Engineering News. [Online] Available: http://www.powerbyproxi.com/communications/news/new-zealand-company-leads-world-wit h-wireless-recharging/

Note 57. Mearian, L. (2013). Intel chooses sides in wireless power market. Computerworld. [Online] Available: http://www.computerworld.com/s/article/9240189/Intel_chooses_sides_in_wireless_power_ market

Note 58. Terkosky, D. (2012). The answer is blowing in the wind. PowerbyProxi. [Online] Available: http://www.powerbyproxi.com/2012/12/the-answer-is-blowing-in-the-wind/

\section{Copyright Disclaimer}

Copyright for this article is retained by the author(s), with first publication rights granted to the journal.

This is an open-access article distributed under the terms and conditions of the Creative Commons Attribution license (http://creativecommons.org/licenses/by/3.0/). 